\title{
RATIONAL EXPECTATIONS AND THE EFFECTS OF FINANCIAL LIBERALIZATION OF PRICE LEVEL AND OUTPUT
}

\author{
Rangan Gupta
}

Department of Economics, University of Pretoria

\begin{abstract}
This paper develops a generalized short-term model of a small open financially repressed economy, characterized by unorganized money markets, intermediate goods imports, capital mobility, flexible exchange rates and rational expectations, to analyze the price- and output-effects of financial liberalization. The analysis shows that financial deregulation, in the form of increased rate of interest on deposits and higher cash reserve requirements, unambiguously and unconditionally reduces domestic price level, but fails to affect output. Moreover, the result does not depend on the degree of capital mobility. The paper recommends that a small open developing economy should deregulate interest rates and tighten monetary policy if reducing inflation is a priority. Such a policy, however, requires the establishment of a flexible exchange rate regime.
\end{abstract}

JEL codes: E31, E44, E52, F41

\section{1 \\ Introduction}

This paper develops a model of a financially repressed small open economy and analyzes the inflationary dynamics following financial liberalization. Specifically, financial restriction consists of three elements: first, the banking system is favoured and protected because the government can finance the budget deficit at a low or zero cost by forcing banks to hold government bonds and money through the imposition of "high" multiple reserve requirements; second, since government revenue cannot be extracted from private securities very easily, the development of private bond and equity markets is discouraged; and, finally, interest rate ceilings are imposed on the banking system to encourage low-cost investment and curtail competition with public sector fundraising from the private sector. In this context, financial liberalization is defined as relaxing the interest rate ceiling and lowering reserve requirements.

Since the break-up of the old colonial empires, many developing economies suffer from stagnant economic growth, persistent inflation and external imbalances under financial repression. To cope with these difficulties, McKinnon (1973) and Shaw (1973) advocate a high interest rate policy to accelerate growth with lower inflation. Such policy prescriptions have come to be associated with the liberal school, which in its analysis assumes that financial sector development is the precursor to economic growth. The influential analysis of financial liberalization initiated by the liberal school has been strongly criticized by a group of economists adhering to the new structuralist school. Advocates of the new structuralist school (Van Wijnbergen,1982, 1983 and 1985; Buffie, 1984; Kohsaka, 1984; Lim, 1987) postulate that the financial markets of developing countries are characterized by competitive and agile unofficial money markets (UMM), which absorb the excess demand for credit from the official banking system - an implication of the interest rate ceilings. They indicate that in such an environment an increase in the nominal interest rate on deposits will cause households to reallocate their portfolios toward bank deposits at the expense of UMM securities, which in 
turn will cause the total supply of credit to the business sector to decline as funds are shifted out of the UMM and into the banking system. This occurs because the banking system, in the presence of reserve requirements, provides partial intermediation whereas the UMM, with no reserve requirements, provides one-to-one intermediation. As a result, this reallocation reduces the total supply of credit, causing the UMM rate to go up to clear the credit market. The associated increase in the cost of funds shifts the aggregate supply to the left, and output falls while inflation rises. (See Karapatakis (1992) for a comprehensive literature review on financial repression.)

Our analysis builds on two recent studies, Nag and Mukhopadhyay (1998) and Gupta (2006). analyzing the effects of financial liberalization on inflation for a small open economy, in the presence of informal money markets. Nag and Mukhopadhyay (1998) show that the new structuralist claim, propagated by Van Wijnbergen (1982, 1983, 1985 and 1986), of a tight monetary policy and interest rate deregulation, is severely altered when one allows for import penetration and flexible exchange rate. Gupta (2006) extends the analysis of Nag and Mukhopadhyay (1998), by incorporating capital account mobility, relaxing the assumption of perfect wage indexation (which is typically not the case in a small open financially repressed country) and endogenizing money supply, to bring in the role of reserve requirements. The study concludes that financial liberalization and tight monetary policy cause deflation in an economy with a high degree of capital mobility. However, for economies with a low degree of capital mobility, the possibility of stagflation cannot be ruled out. The paper recommends financial liberalization in the form of lower reserve requirements for economies with restricted transactions in the capital account.

Even though both these studies are insightful, neither of them endogenizes expectations. This paper, therefore, basically extend Gupta's study (2006) by allowing agents to form expectations rationally. However, the model used in this paper only allows agents to choose from a variety of variables offered as state variables in the model, limited by the policy parameters, and, hence, the expectations, though freely and rationally chosen, are determined from within the model, and not through any arbitrary expectations equations as is the case for adaptive expectations. The expectations are, thus, endogenous. To the best of my knowledge, this study is the first to attempt to analyze the shortterm effects of financial liberalization based on rational expectations.

Using rational expectations, instead of exogenous expectations as in $\mathrm{Nag}$ and Mukhopadhyay (1998) and Gupta (2006), this study shows that higher interest rates on deposits and tighter monetary policy are, unambiguously and unconditionally, deflationary. Moreover, the effects do not depend on the degree of capital mobility. This study recommends that a small open developing economy should deregulate interest rates and tighten monetary policy if reducing inflation is a priority. The pre-requisite for such a policy, however, is the establishment of a flexible exchange rate regime.

This paper is structured in the following fashion: Besides the introduction and conclusion, section 2 lays out the economic environment and section 3 solves the model and discusses the effects of financial liberalization on the rate of inflation.

\section{2 The model}

This model considers a small open economy, operating under a floating exchange rate regime, with one domestically produced good and two different types of imported goods (a consumption good and an imported intermediate good, used in the production of domestic output). The price of the domestic good is endogenous, whilst the price of the imported goods, both consumption and capital, are exogenous. The supply function of the importables is perfectly elastic at a foreign currency price of $P^{*}$. Since $P^{*}$ is parametrically given to the economy, it can be set to unity for the sake of simplicity. Notice the implicit assumption that the production transformation schedule is linear for the imported consumption good and the intermediate good, so that the same technology applies to both kinds of importables and they sell for the same price of $P^{*}$. 
Repression is assumed to be severe enough to give rise to a UMM, popularly called a curb market. The curb market is an informal credit market in which money lenders and indigenous banks intermediate between savers and borrowers, and are outside the realm of regulation by the monetary authority. Because of the absence of reserve requirements, the curb market is often viewed as a competitive and agile credit market providing more efficient intermediation than the official banking system. Moreover, since the banking system operates under interest rate regulations and high reserve requirements, the curb market can be viewed as a residual market that absorbs the excess demand for credit from the official banking system.

Firms unable to obtain low cost funds from the banking system at the regulated lending rate turn to the UMM to satisfy their borrowing needs to finance intermediate input and physical capital requirement. The freely determined rate in the curb market is much higher than the deposit and loan rates in the official banking system, and reflects the true marginal cost of production. Hence, the UMM rate of interest appears as an argument in both the aggregate demand and aggregate supply side of the model.

Our model of a small open financially repressed economy is a modified version of the standard Mundell-Fleming model as outlined in Argy (1994) and Walsh (2000). The basic structure of the economy can be laid out by considering the factors of four interrelated markets, namely the production, commodity, money and foreign exchange markets. We start off with the labour market. Unlike the standard Mundell-Fleming model, the aggregate supply curve in this model is not perfectly elastic but slopes upward under reasonable assumptions about wage-price flexibility.

Since this is a short-run model, the aggregate supply is determined by the conditions prevailing in the labour market and by the cost of the imported intermediate good requirement, as shown in equation 1 :

1n $\left.Q_{t}^{S}=-\beta_{1}\left[\left(1 \mathrm{n} \rho_{t}\right)+\mathrm{r}_{c t}\right]-\beta_{2}\left[1 \mathrm{n} W_{t}-1 \mathrm{n} P_{t}\right)\right]+$ $\lambda_{t}$ where, $W, P_{d}$, $\rho$ and $r_{c}$ represent nominal wage, domestic price level, real exchange rate and real interest rate of the curb market, respectively, with $\rho=s P^{*} / P$, where $s$ is the nominal exchange rate; $\beta_{i}^{\prime} s>0, i=1,2$ and $\lambda_{t} \sim N\left(0, \sigma_{\lambda}^{s}\right)$.

Equation 1 states that the quantity supplied is negatively related to the marginal cost of hiring one additional unit of labour and the intermediate imported input. Note that wage cost is assumed to be financed through retained earnings of the firms. However, the intermediate input is purchased through loans from both banks and the UMM. This is merely a simplification, and assuming that labour costs are also loan-financed, does not change our final results, but allows us to be parsimonious with the number of coefficients. The intuition is that the firms do not want to tie up their retained earnings with the foreign suppliers and, moreover, the foreign suppliers require advance payment and, hence, the firms' reliance on loans. Thus, the interest rate of the curb market, which reflects the true marginal cost of production, enters as an argument into the aggregate supply curve, as well as the real exchange rate.

To analyze how the nominal wage rate is determined we need to focus on the labour market, and specifically the labour demand and supply equations. Labour demand depends negatively on real wage, while labour supply follows a Friedman-Phelps type of function, where the same depends positively on the expected real wage rate. The intuition behind such a formulation is that labour supply decisions are made on the basis of a one-periodahead nominal wage contract, with nominal wages being contracted to achieve a target level of real wage, based on the price level expected to prevail during the period for which the contract is being drawn up. However, given that firms are fully aware of the price level when making their labour demand decisions, the latter depends on actual real wage. Formally,

1n $N_{t}^{d}=f_{0}-f_{1}\left(1 \mathrm{n} W_{t}-1 \mathrm{n} P_{t}\right)+\chi_{t}$
1n $N_{t}^{\mathrm{s}}=f_{2}+f_{3}\left(1 \mathrm{n} W_{t}-1 \mathrm{n} E_{t-1} P_{t}\right)+\kappa_{t}$

where $f_{i}>0, i=1,2,3,4, f_{0}>f_{2}, \chi_{t} \sim$ $N\left(0, \sigma_{x}^{s}\right)$ and $\kappa_{t} \sim N\left(0, \sigma_{\mathrm{k}}^{s}\right)$. 
Imposing labour market equilibrium, $N_{t}^{d}=N_{t}^{s}$ , we can solve for the equilibrium nominal wage rate from equations 2 and 3 in terms of the price level and its expectations. We obtain the following relationship,

$\ln W_{t}=\frac{f_{2}-f_{0}}{f_{1}+f_{3}}+\frac{1}{f_{1}+f_{3}}\left(f_{1} \ln E_{t-1} P_{t}+f_{3} \ln P_{t}\right)+$

$\frac{\chi_{t}-\kappa_{t}}{f_{1}+f_{3}}$

Substituting 4 into 1 , we have the aggregate supply equation as follows:

$\ln Q_{t}^{s}=b_{0}-b_{1}\left(\ln \rho_{t}+r_{c t}\right)+b_{2}\left(\ln P_{t}-\ln E_{t-1} P_{t}\right)+e_{t}$

Where $b_{i}>0, i=0,1,2$, and $b_{0}=\frac{\beta_{2}\left(f_{0}-f_{2}\right)}{f_{1}+f_{3}}$ $, b_{1}=\beta_{1}, b_{2}=\frac{\beta_{2} f_{1}}{f_{1}+f_{3}}, e_{t}=\lambda_{t}+\beta_{2} \frac{\left(\kappa_{t}-\chi_{t}\right)}{f_{1}+f_{3}}$

and $e_{t} \sim N\left(0, \sigma_{e}^{2}\right)$.

Next, we turn our attention to the commodity market. The aggregate demand is positively related to the real exchange rate $(\rho)$, while real interest rate in the curb market $\left(r_{c}\right)$ negatively influences the domestic investment demand and, hence, the aggregate demand. With the level of government expenditure $(G)$ and foreign output $\left(Y_{f}\right)$ treated as exogenous, the effects are captured in the disturbance term $u$. We postulate an IS curve of the following nature:

$\ln Q_{t}^{d}=a_{1} \ln \rho_{t}-a_{2} r_{c t}+u_{t}$

where $a_{i}$ 's $>0, i=1$ and 2 , and $u \sim N\left(0, \sigma_{u}^{2}\right)$.

Before we look into the money market, it is worthwhile briefly discussing the structure of the banking sector. The central bank sits at the apex of all monetary activities, and maintains stability by controlling the base money and credit availability in the economy. For this purpose, the central bank imposes reserve ratio requirements on commercial bank deposits and interest rate regulations on loans and deposits. The UMM is outside the realm of the central bank and so is subjected to neither interest rate control nor reserve requirements. The freely determined interest rate of the curb market helps in clearing the money market.
To incorporate the role of reserve requirements we endogenize the supply of money. The money demand equation is designed to follow the new structuralist understanding. Given this, the nominal demand function for money is given as follows:

$\ln M_{t}^{d}-\ln q_{t}=\delta_{1} \ln Y_{t}+\delta_{2} i_{d}-\delta_{3} i_{c t}+\xi_{t}$

where $M_{t}^{d}, Y_{t}, i_{d}, i_{c t}$ are respectively the nominal money demand, real gross domestic product, nominal interest rate on deposits and nominal interest rate on the curb market loans. $\mathrm{q}$ is the Consumer Price Index (CPI). We define the $\mathrm{CPI}$ as $\ln \mathrm{q}=\mathrm{j} \ln \mathrm{P}+(1-\mathrm{j}) \ln s$, where $\mathrm{j}$ is the share domestic output in the CPI. Note, $\delta_{i}$ 's $>0$, $\mathrm{i}=1,2,3$ and $\xi \sim N\left(0, \sigma_{\xi}^{2}\right)$.

Following the new structuralist argument, we assume that a rise in the bank deposit rate causes a reallocation in households' portfolios toward bank deposits at the expense of UMM securities and not cash, thus causing money demand to increase. Similarly, a rise in UMM rate of interest causes a reallocation towards UMM securities at the expense of bank deposits, thus causing money demand to decrease. This is not an irrational assumption for a developing country, especially when one realizes that most goods are cash goods and hence the demand for currency is pretty inelastic in relation to changes in opportunity cost variables. (see Van Wijnbergen 1982, 1983 and 1985; Buffie, 1984; Kohsaka, 1984 and Lim, 1987; Nag \& Mukhopadhyay, 1998 and Nag, 2000, for the theoretical validity of such a formulation of money demand in a financially repressed economy, and Van Wijnbergen, 1982 and 1985, and Lim, 1987 for empirical support of the same.)

On the other hand, the money supply function can be formulated as follows. Money supply is a sum of currency in circulation (C) and supply of bank deposits (D) and base money, or high powered money $(\mathrm{H})$ is the sum of currency and reserves $(\mathrm{R})$. Thus $\left(M^{s}\right) / H=((C / D)+1) /(C /$ $D+R R / D+E R / D)$, where $R R$ and $E R$ are required and excess reserves respectively, and $M^{s}$ is the nominal supply of money. Alternatively, $M^{s}=((1+c u) /(c u+\gamma+e r)) H$, where $c u$ is the currency deposit ratio, $\gamma$ the required reserve 
ratio and $e r$ the excess reserves to deposit ratio.

Simple intuition suggests that the currency deposit ratio and the excess reserve to deposit can be postulated as a negative function of $Y$, and $i_{d}$ and a positive function of $i_{c}$. The rationale for the sign of the currency-deposit ratio with respect to the interest rates is obvious, given that the currency demand is pretty inelastic with respect to interest rate movements. However, as $Y$ increases, both $C$ and $D$ rise, but, given that with the growth of banking habits, more payments are settled through banks, deposits increase at a faster rate than currency. Hence, the currency-deposit ratio can be postulated to be negatively correlated with the level of income. On the other hand, as income and interest rates in the curb market increase, er falls and rises respectively. And as the interest rate on deposits rises, deposits rise and excess reserve holdings fall, since the interest rate on loans in the official banking sector is also increased to maintain profitability, causing er to fall.

Taking these arguments into account, and realizing that increases in $\mathrm{cu}$ and $\mathrm{er}$ reduce the money multiplier, the money supply function in log terms can be constructed as follows:

$$
\ln M_{t}^{s}=\eta_{1} \ln Y_{t}+\eta_{2} \bar{i}_{d t}+\eta_{3} i_{c t}+\ln H_{t}-\gamma+\psi_{t}
$$

where, $\eta{ }^{\prime} \mathrm{s}>0, i=1,2,3$ and $\psi \sim N\left(0, \sigma_{\psi}^{2}\right)$. Combining 7 and 8 and realizing that the Fisher relationship links the real rate of interest with the nominal rate of interest as $r_{c t}=i_{c t}-E_{t} \ln P_{t+1}+\ln P_{t}$, we have the following equation from the money market equilibrium:

$$
\begin{aligned}
& \ln H_{t}-\left(j \ln P_{t}+(1-j) \ln s_{t}\right)=\gamma-d_{1} \\
& \left(r_{c t}-\ln P_{t}+E_{t} \ln P_{t+1}\right)+d_{2} \bar{i}_{d t}+d_{3} \ln Y_{t}+v_{t}
\end{aligned}
$$

where, $d_{i}$ 's $>0, i=1,2$ and 3 , $d_{1}=\eta_{3}+\delta_{3}, d_{2}=-\eta_{2}+\delta_{2}, d_{3}=-\eta_{1}+\delta_{1}$, and $v_{t}=\xi_{t}+\psi_{t}$ with $v \sim N\left(0, \sigma_{v}^{2}\right)$. Note that we are assuming that the money demand function is more elastic with respect to real income than the money supply. This assumption is required to ensure that the aggregate demand curve is negatively sloped. Moreover, given that the new structuralists assume that an increase in the nominal interest rate on deposits will result in higher interest rate in the curb market to clear the money market, we have to assume that the money demand function is more elastic to nominal interest rate on deposits than the money supply function.

The choice of the appropriate exchange rate regime is surely a controversial issue. But as Nag and Mukhopadhyay (1998) and Nag (2000) point out, since developing countries depend to a significant extent on imports of intermediate inputs and lack growth of exports due to structural bottlenecks, it is difficult to maintain a fixed exchange rate regime. The tremendous pressure on the balance of payments in an open economic environment inevitably leads to the adoption of flexible policies of exchange rate. In this paper, we assume that the monetary authority allows the exchange rate to float freely. Accordingly, the equilibrium in the foreign exchange market is given by the following equation:

$$
\begin{aligned}
& B_{t} / X_{0}=c_{1} \ln \rho_{t}-\ln Y_{t}+c_{2} 1 \\
& \left(r_{c t}-r^{*}-\left(E_{t} \ln \rho_{t+1}-\ln \rho_{t}\right)\right)+\Phi_{t}
\end{aligned}
$$

where, $c_{i}^{\prime} s>0, i=1$ and 2, with $c_{1}>\alpha_{1}, r^{*}$ is the world real rate of interest. With foreign output $\left(Y_{f}\right)$ treated as exogenous, the effects are captured in the disturbance term $(\varpi)$ and

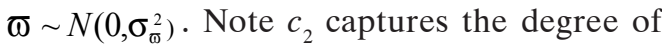
capital mobility. The parameter can range between zero to infinity, indicating no and perfect capital mobility, respectively. Any positive intermediate value reflects imperfect capital mobility. Equation 11 defines the overall balance of payments given initial exports $\left(X_{0}\right)$, where the first four terms determine the current account balance. The last term gives us the capital account balance. Equilibrium in the foreign exchange market would imply the balance of payments $(B P)=0$.

Finally, to complete the model we need to specify the policy reaction function for highpowered money as follows:

1n $H_{t}-\mu+g_{1} e_{t}+g_{2} u_{t}+g_{3} v_{t}+g_{4} \bar{\varpi}_{\mathrm{t}}$

The policy rule specified allows the policy maker to respond contemporaneously to supply shock, aggregate-demand shock, money-demand shock and shock in the foreign exchange market. Our final result of financial liberalization on inflation 


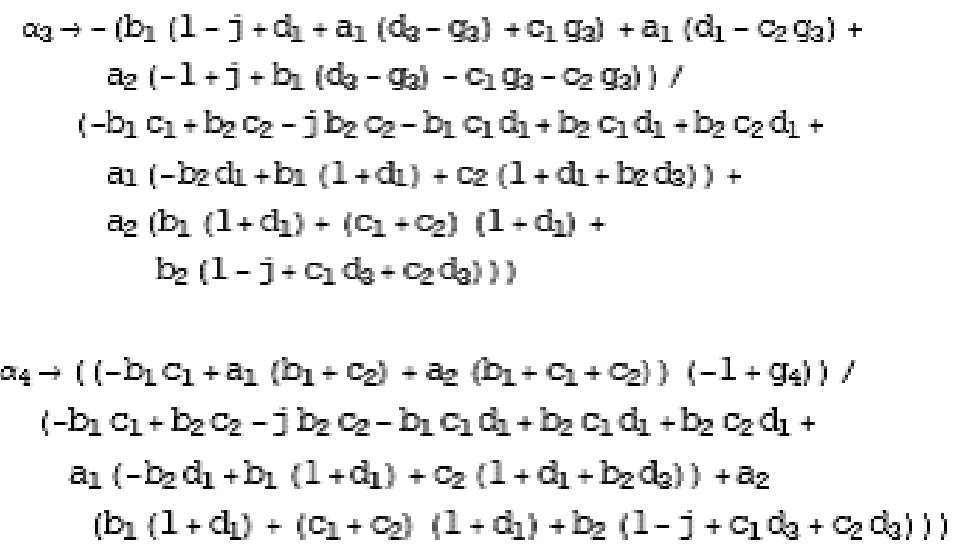

Note that we are treating the nominal interest rate on deposits, the world rate of interest and the reserve-requirements as time invariant, since these are exogenous variables. And, hence, they appear in $\alpha_{0}$. Our analysis would not change if the variables were treated as time-variant, once we postulated the solutions for for $\ln P, \ln s, r_{c}$ and $\ln Y$ to include coefficients corresponding to $i_{d}, \gamma, \mu$.

To study the effects of financial liberalization on domestic price level, we take the derivative of $\alpha_{0}$ with respect to $i_{d}, \gamma, \mu$ to obtain $-d_{2}$, $-1,1$. The results indicate that financial liberalization, in the form of an increase in the rate of interest on deposits, and tight monetary policy is unambiguously and unconditionally deflationary. Moreover, the result does not depend on the degree of capital mobility, and the only pre-requisite for such an outcome is the establishment of a flexible exchange rate regime. Moreover, given that

$$
\theta_{0} \rightarrow \frac{a_{1}\left(b_{0}-r^{*} b_{1}\right) c_{2}+a_{2}\left(b_{0} c_{1}-r^{*} b_{1} c_{2}\right)}{a_{2}\left(b_{1}+c_{1}\right)+a_{1}\left(b_{1}+c_{2}\right)+b_{1}\left(-c_{1}+c_{2}\right)}
$$

the solution to output is unaffected by the change in the controlled nominal interest rate on deposits and reserve requirements. In rational expectation models, a policy is said to be neutral if the unconditional mean and variance of the solution of the output is independent of the policy parameters. So, in this sense, policy is neutral with respect to $i_{d}, \gamma, \mu$. However, monetary policy is not completely neutral, since even though the unconditional mean of the output is independent of the policy reaction function parameters $\left(g_{i}\right.$ 's), they appear in the variance of the solution of the output. Notethat the following are the other coefficients of the postulated solution of the output:

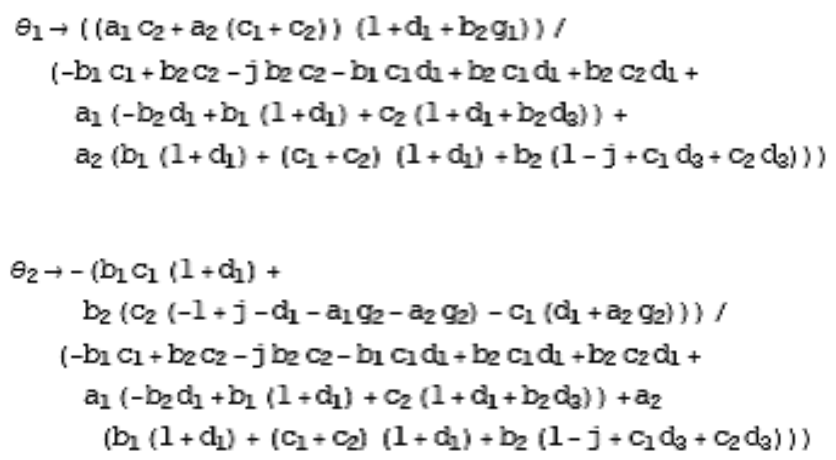




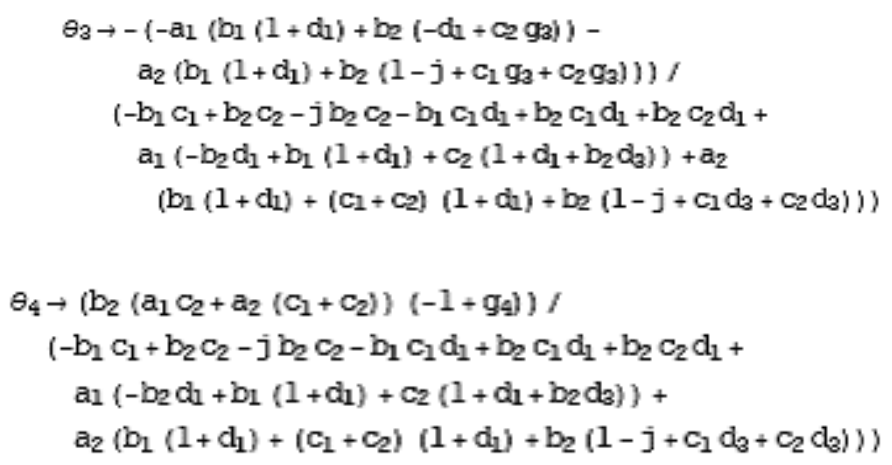

Interestingly, Gupta (2006) obtains exactly the same results with perfect wage indexation but exogenous expectations.

\section{4}

\section{Conclusion and areas of further research}

This study modifies the standard MundellFleming model and analyzes the effects of financial liberalization on domestic price level and GDP. Considering a small open financially repressed economy characterized by a UMM, intermediate good imports, capital mobility and endogenous expectations, we show that interest rate deregulation is inflation-reducing. However, financial liberalization fails to affect output. The stagflationary outcome of interest rate deregulation, as claimed by the new structuralists, is thus not an obvious outcome in such an environment. This study thus recommends that a small open developing economy should deregulate interest rates and tighten monetary policy if reducing inflation is a priority. The pre-requisite, however, is establishment of a flexible exchange rate regime.

As a future area of research, it would be interesting to analyze the long-term effects of financial liberalization on growth and inflation in a micro-founded dynamic general equilibrium endogenous growth model with a role for money.

\section{Endnotes}

This paper was written as a follow-up to my paper titled, "Financial Liberalization And Inflationary Dynamics in the Context Of A Small Open Economy".

\section{References}

1. ARGY, V. (1994) International Macroeconomics: Theory and Policy, Routledge: London and New York

2. BUFFIE, E. (1984) "Financial repression, the new structuralists, and stabilization policy in semiindustrialized economies", Journal of Development Economics, 14: 451-482.

3. GUPTA, R. (2006), "Financial liberalization and inflationary dynamics in the context of a small open economy", South African Journal of Economic and Management Sciences, 9: 89-101.

4. KARAPATAKIS, A. (1992) Financial Liberalization and Inflation in a Small Open Financially Repressed Economy: Theory, and Evidence from Cyprus. Dissertation, University of Connecticut: USA.

5. KOHSAKA, A. (1984) "The high interest rate policy under financial repression", Developing Economies, 22: 419-452.

6. LIM, J. (1987) "The new structuralist critique of the monetarist theory of inflation: The case of Philippines", Journal of Development Economics, 25: 377-386.

7. McCALLUM, T.B. (1989) Monetary Economics: Theory and Policy, Macmillan: New York. 
8. McKINNON, R. (1973) Money and Capital in Economic Development, Brookings Institution: Washington, D.C.

9. NAG, R. (2000) "Stabilization dynamics and nonbank financial intermediaries", Indian Economic Review, 35: 193-209.

10. NAG, R. \& MUKHOPADHYAY, M. (1998) "Macro-economic effects of stabilization under financial liberalization", Indian Economic Review, 33: 1-17.

11. SHAW, E. (1973) Interest Controls and Credit Allocations in Developing Countries. Oxford University Press: New York.

12. VAN WIJNBERGEN, S. (1982) "Stagflationary effects of monetary stabilization policies: A quantitative analysis of South Korea”, Journal of Development Economics, 10: 133-169.
13. VAN WIJNBERGEN, S. (1983) "Interest Rate Management in LDCs", Journal of Monetary Economics, 12: 433-452.

14. VAN WIJNBERGEN, S. (1985) "Macroeconomic effects of changes in bank interest rates: Simulation results for South Korea", Journal of Development Economics, 18: 541-554.

15. VAN WIJNBERGEN, S. (1986) "Exchange Rate Management and Stabilization Policies in Developing Countries", Journal of Development Economics, 23: 227-247.

16. WALSH, C. (2000) Monetary Theory and Policy, The MIT Press: Cambridge, Mass. 